\title{
Ethnobotanical survey on insecticidal and repellent plants in the Republic of Congo
}

\author{
${ }^{1}$ Mikolo Bertin and ${ }^{2}$ Mananga Vital \\ ${ }^{1}$ National Polytechnic High School, Marien Ngouabi University, PO Box: 69, Brazzaville, Republic of Congo \\ Tel: +242068641803 \\ ${ }^{2}$ Faculty of Sciences and Techniques, Marien Ngouabi University, PO Box: 69, Brazzaville, Republic of Congo \\ Email: manangavital@yahoo.fr \\ Corresponding author email: mikolobertin@yahoo.fr
}

Original submitted in on $15^{\text {th }}$ January 2020. Published online at www.m.elewa.org/journals/ on $30^{\text {th }}$ April 2020 https://doi.org/10.35759/JABs.148.5

\begin{abstract}
Objective: The study aimed to collect data about natural products that are traditionally used for controlling insects that are harmful to human health.

Methodology and results: Investigation was undertaken in the departments of Sangha, in the north (Lékoumou, Niari) and Kouilou in the south of the Republic of Congo, using a questionnaire. Informants were asked to provide information about plant materials used to prevent insect responsible for nuisance and transmission of disease to humans and pets. Results showed that the respondents knew plants with antimosquitoes (62.5\%), anti-lice (76.1\%), anti-tungiasis (70.4\%) anti-chicken fleas (61.4\%) and anti-dog fleas $(45.4 \%)$ properties. The respondents cited some species that were identified either in the field or in the national herbarium, making a total of 34 plants identified. The plants cited appear in two groups: repellent and toxic. The first group includes plants such as Elaeis guineensis, Lantana camara, Ocimum gratissimum and Cymbopogan citratus, which repel mosquitoes, dog fleas and chicken fleas, and, the second includes Mucuna sloanei, Piptadeniastrum africanum, Strychnos icaja, Croton mayumbensis and Nicotiana tabacum that kill tungiasis and head lice. The part of plants along with their specific usage has been described.

Conclusion: Botanical materials are still widely used in Congo to repel and control insects. This study provides information that can be used in the discovery and development of new, more affordable and safer products to control harmful insects.
\end{abstract}

Key words: plants, insect, repellent, vector, Congo

\section{INTRODUCTION}

Control of insect vectors of human diseases remains one of the great concerns in public health, particularly in tropical countries. Until now, application of insecticidal compounds is one of the main control measures recommended by WHO. However, due to the side effects of insecticides, occurrence of resistance in mosquitoes and intoxication to humans and the environment, efforts are being made to produce safer and cheaper chemicals including repellents. Many insecticidal and repellent plant materials and some pathogens have been tested on insect vectors of diseases (Weiser and Žizka 2004). The purpose is to avoid insect bites either by killing or by repelling the vectors. Bites are currently avoided by use of insect repellents, most of them made with DEET $(\mathrm{N}, \mathrm{N}$ - 
diethyl-m-toluamide) or botanical oils (Peterson and Coats 2001). Patel et al. (2012) has reported different methods used for mosquito repellent applications. Many repellents and insecticides are derived from plant materials or their analogues. The Congolese forest is part of the Congo Basin, which is the second largest forest reserve in the world after Amazon with 10,000 species including 6,000 existing in the Republic of Congo (Devers and Van de Weghe 2007; De Wasseige et al., 2012). The significant biodiversity suggests the existence of complex interactions between insects and other living things that coexist there. There is high potential to identify resources in the Congolese forest that can be used to resolve some of the

\section{MATERIALS AND METHODS}

Description of the study sites: Investigations were carried out in southwest Congo, particularly in the departments of Lékoumou, Niari and Kouilou and in the problems of human and environmental intoxication and the resistance of insects induced by the excessive use of conventional pesticides. In this perspective, there exists abundant literature that reveals the effects of the derivatives of numerous species of plants, of some microorganisms and other invertebrates on harmful insects. The purpose of this work was to investigate traditional Congolese knowledge in the control of insects that are harmful to human health. The specific objectives were to inventory the natural products traditionally used against harmful insects, identify the plant species utilized, and inventory the procedures for using the identified plants.

north in Sangha. The localities visited are listed in Table 1 along with the local ethnic groups and the geographical coordinates of plant location.

Table 1: Localities visited and corresponding ethnic groups

\begin{tabular}{|c|c|c|c|}
\hline Departments & Localities & GPS coordinates & Ethnic groups \\
\hline \multirow{9}{*}{ Lékoumou } & Moukanda & $\mathrm{S}^{2} 3^{\circ} 39.389^{\prime} \mathrm{E} 013^{\circ} 21.226^{\prime}, 547 \mathrm{~m}$ & Teke, Yaka \\
\hline & Mongo & $\mathrm{S}^{2} 3^{\circ} 37.290^{\prime} \mathrm{E} 013^{\circ} 22.272^{\prime}, 489 \mathrm{~m}$ & Yaka \\
\hline & Loyo & $\mathrm{S}^{2} 3^{\circ} 30.763^{\prime} \mathrm{E} 013^{\circ} 22.667^{\prime}, 496 \mathrm{~m}$ & Yaka, Lali, \\
\hline & Panda & $\mathrm{S}^{2} 3^{\circ} 39.841^{\prime} \mathrm{E} 013^{\circ} 24.584^{\prime}, 489 \mathrm{~m}$ & Lali \\
\hline & Moufilou & $\mathrm{S}^{\prime} 03^{\circ} 41.339^{\prime} \mathrm{E} 013^{\circ} 29.029^{\prime}, 464 \mathrm{~m}$ & Autochthones \\
\hline & Lilende & $\mathrm{S}^{2} 3^{\circ} 42.046^{\prime} \mathrm{E} 013^{\circ} 71908^{\prime}, 453 \mathrm{~m}$ & Lali \\
\hline & Bengue & $\mathrm{S}^{2} 3^{\circ} 28.418^{\prime} \mathrm{E} 013^{\circ} 24.167^{\prime}, 519 \mathrm{~m}$ & Bambamba \\
\hline & Mambouana & $\mathrm{S}^{2} 3^{\circ} 29.911^{\prime} \mathrm{E} 013^{\circ} 19.170^{\prime}, 489 \mathrm{~m}$ & Yaka \\
\hline & Makanda & $\mathrm{S}^{2} 03^{\circ} 42.229^{\prime} \mathrm{E} 013^{\circ} 30.807^{\prime}, 471 \mathrm{~m}$ & Lali \\
\hline \multirow[t]{10}{*}{ Niari } & Mokonzi 1 & $\mathrm{~S}^{2} 4^{\circ} 10,371^{\prime} \mathrm{E} 012^{\circ} 48.644^{\prime}, 352 \mathrm{~m}$ & Kouni \\
\hline & Makoundji & $\mathrm{S}^{2} 3^{\circ} 57.748^{\prime} \mathrm{E} 012^{\circ} 35.819^{\prime}, 207 \mathrm{~m}$ & Kouni \\
\hline & Mokonzi 2 & $\mathrm{~S}^{\circ} 4^{\circ} 10.258^{\prime} \mathrm{E} 012^{\circ} 49.754^{\prime}, 378 \mathrm{~m}$ & Kouni \\
\hline & Mbouma & $\mathrm{S}^{2} 3^{\circ} 58.729^{\prime} \mathrm{E} 012^{\circ} 36.566^{\prime}, 216 \mathrm{~m}$ & Kouni \\
\hline & llou Panga & $\mathrm{S}^{\prime} 4^{\circ} 22.701^{\prime} \mathrm{E} 012^{\circ} 49.301^{\prime}, 435 \mathrm{~m}$ & Basoundi \\
\hline & Kikassa & $\mathrm{S}^{2} 4^{\circ} 17.737^{\prime} \mathrm{E} 12^{\circ} 46.435^{\prime}, 390 \mathrm{~m}$ & Basoundi, Bakouni \\
\hline & Kibindouka & $\mathrm{S}^{2} 4^{\circ} 00.893^{\prime} \mathrm{E} 012^{\circ} 37.746^{\prime}, 250 \mathrm{~m}$ & Pounou \\
\hline & Kimomgo & $\mathrm{S}^{\prime} 4^{\circ} 29.132^{\prime} \mathrm{E} 012^{\circ} 56.923^{\prime}, 405 \mathrm{~m}$ & Basoundi \\
\hline & Yandza & $\mathrm{S}^{\prime} 4^{\circ} 24.619^{\prime} \mathrm{E} 012^{\circ} 53.252^{\prime}, 376 \mathrm{~m}$ & Basoundi \\
\hline & $\begin{array}{l}\text { Mboungou } \\
\text { Louvakou }\end{array}$ & $\mathrm{S}^{\circ} 3^{\circ} 58.255^{\prime} \mathrm{E} 012^{\circ} 36.123^{\prime}, 208 \mathrm{~m}$ & Bakouni \\
\hline \multirow[t]{4}{*}{ Sangha } & Paris & N0133.344'E015³8.712', $469 \mathrm{~m}$ & Bakouele \\
\hline & Ouesso & 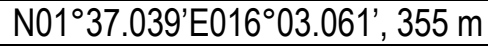 & Bakouele \\
\hline & Keta & 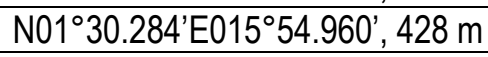 & Autochthones, Bakouele, Sangha \\
\hline & Les Saras & $\mathrm{S}^{\prime} 4^{\circ} 21.204^{\prime} \mathrm{E} 012^{\circ} 21.717^{\prime}, 84 \mathrm{~m}$ & $\begin{array}{l}\text { Yombe, Vili, Lari, Bembe, Loumbou, } \\
\text { bambamba }\end{array}$ \\
\hline
\end{tabular}


Investigations in Kouilou and Niari took place in villages located in the Mayombe forest and surroundings along four axes: Dolisie-Les Saras, Dolisie-Kimongo, DolisieLouvakou and Dolisie-Loudima. In Lekoumou, investigations were along two axes: Sibiti-Mayéyé and Sibiti-Zanaga, in Sangha in the villages located in the Sangha forest from Ouesso to Makoua and Ouesso to Sembé. The Sea in the west, Cabinda and D.R. Congo in the southwest and Gabon in the southeast limit the localities in the southwest. The north is limited by the department of Plateau that separates the northern and southern Congolese regions. Communications are more developed in the south where the flow of knowledge should be greater between communities than in the north. The Sangha department is covered with the forest and is limited in the north by Cameroun and the Congolese Northern department of Likouala; in the east by D.R. Congo; in the south by the department of Cuvette and in the west by Gabon.

Completion of questionnaire and collection of plant samples: Investigations started by meetings with local administration authorities to obtain their consent and interest. We informed the persons met of international regulations about intellectual properties and their rights to prevent exploitation of their traditional knowledge for

\section{RESULTS}

A total of eighty eight (88) informants have been interviewed, including 50 in Kouilou-Niari, 27 in Lekoumou and 11 in Sangha. Results of their responses concerning their knowledge of anti-insect plants are shown in Table 2 while the list of plants identified is shown in Table 3. Other plants that are not included in this list are subject to further identification.

Knowledge of respondents of plant materials used for controlling insect pests: The results showed that, in all the departments there were people who stated to know plants with anti-mosquitoes $(62.5 \%)$, anti-lice (76.1\%), anti-tungiasis (70.4\%) anti-chicken fleas (61.4) and anti-dog fleas (45.4\%) properties (Table 2). The knowledge was higher in the deep forest departments of Lékoumou (92\%) and Sangha (100\%), particularly concerning the products against lice. There was also significant difference between the yes and no frequencies in these two departments, unlike in Kouilou and Niari. These departments are entirely covered with forest and are among the most distant from the main urban areas/cities. Traditional knowledge therefore commercial purposes. A member of the local community was appointed by the Chief of the locality to act as both interpreter and guide for the plant specimen collection. The plan implemented was to meet at least three people available by ethnic group in each locality, starting with the person closest to the starting point. Informants were met randomly either individually according to their disposal or in groups. Interviews were done following a questionnaire with the questions based on the knowledge, local names and usage of plants for controlling mosquitoes, lice, tungiasis and fleas. The interviews were individual, and the informants were selected independent of their age or gender. Names of contacted persons, GPS coordinates and responses were recorded. The common plants mentioned by respondents were identified in the field and the others at the national herbarium in Brazzaville. For some other plants growing far from villages, specimens were obtained from other villages or bought in the city markets.

Data analysis: The graph was constructed using Excel software. Frequencies of respondents about their knowledge of anti-insect plants were compared by calculating the Chi-square values.

predominates there. In the Kouilou and Niari, the proportions of those aware and those not aware was almost equal. The populations make much more use of manufactured products that are more available and effective than natural products.

General plants identified: A total of 34 plants mentioned were identified including 15 used against mosquitoes, 13, 12, 10, and 4 against chicken fleas, tungiasis, hair lice and dog-fleas respectively (Table 3). The most cited plant materials were those against dog fleas (28 times), followed by those against chicken fleas (24 times), mosquitoes (17 times), tungiasis (17 times) and lice (13 times). The most of them for controlling mosquitoes, followed by those used against tungiasis, head lice, chicken and dog fleas. The most cited plant out of the 34 identified was Elaeis guineensis (19 times), followed by Nicotiana tabacum, Capsicum annuum, Ocimum gratissimum, Mucuna sloanei, Musa acuminata and Strychnos sp, which were cited, between 6 to 4 times (Figure 1). The remaining plants were cited once. 


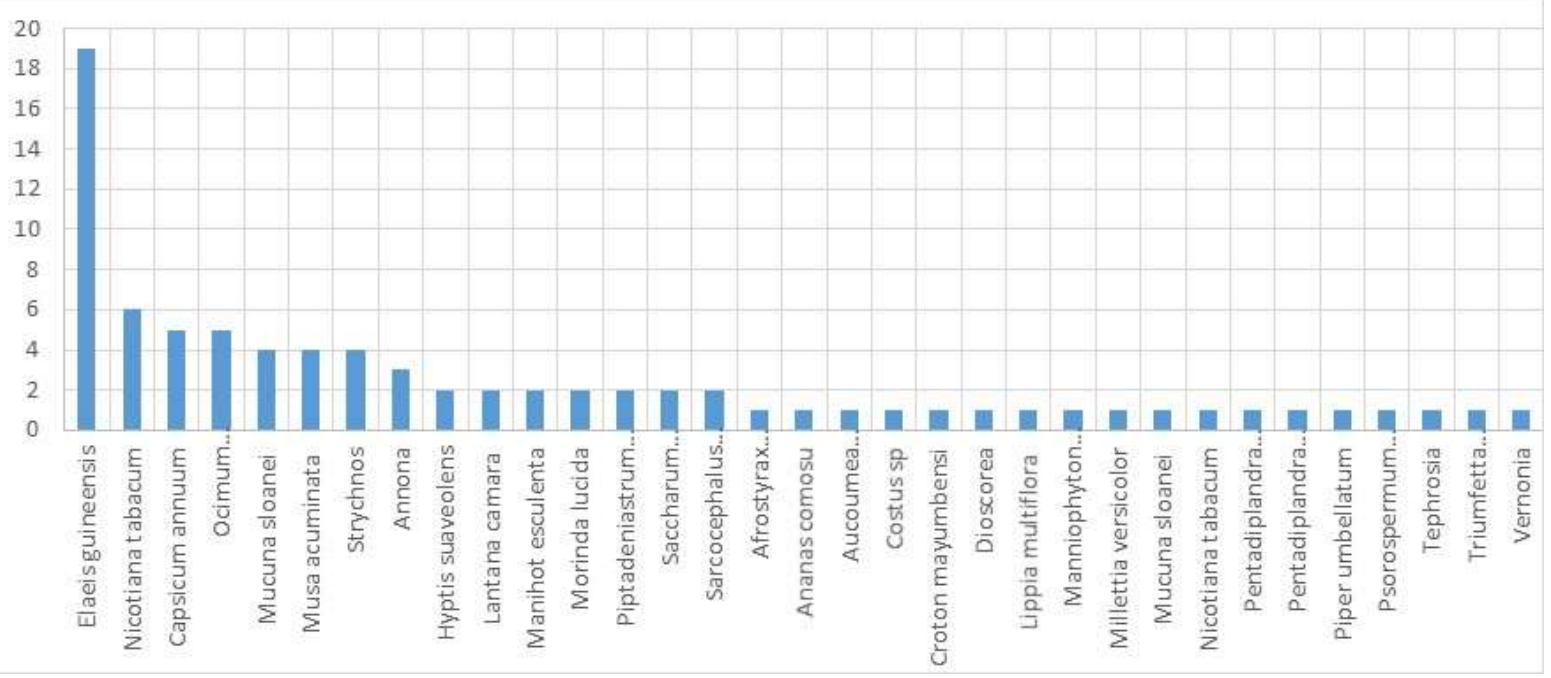

Figure 1: number of citations of each species identified

Anti-mosquitoes: Fifteen plant materials were cited including the inflorescence of Elaeis guineensis (palm) 7 times out of $27(40.7 \%)$, followed by Ocimum gratissimum (18.5\%), Saccharum officinarum (7.4\%) and other that have only been mentioned once $(2.7 \%)$. They have been all cited for their supposed repellence activity. They are burnt to repel mosquitoes. Materials from Nicotiana tabacum tobacco), Ocimum gratissimum and Musa acuminata are triturated and the juice applied to the skin to protect oneself against mosquito bites.

Pediculicidal plants: In Kouilou and Niari, thirty-one informants (18\%) cited 9 plants, Mucuna sloanei being the most anti-insect cited (Table 3 ). It is a leguminous seed whose powder is mixed with palm oil and applied to hair to kill head lice. In Lekoumou, respondents cited 14 plants used for this purpose, including Mucuna sloanei at $40.7 \%$. Annona seneglensis was the second most plant cited for its pediculicidal activity.

Plants with effects on chicken fleas: The common plant materials used against chicken fleas, among the 13 named by respondents, were those from Manihot esculenta, Capsicum annuum (Piper) and Elaeis guineensis (Table 3). The extract from fermented cassava root is pulverized on the chicken nest. Piper fruits are ground and poured on the nest while palm inflorescence can also be put on the chicken nest; it

\section{DISCUSSION}

Among the plants identified by the respondents in the survey areas, many are well known and have been reported in numerous publications, e.g. Leguminoseae (Ningombam et al.,2017); Rubiaceae such as Morinda (Owolabi et al,.2014); Fabaceae from the genus attracts fleas and is then burnt after 24 hours. Palm nut cake is used as incense burnt on the chicken nest. Leaves of tobacco and other plants cited are also effective when placed around the chicken nest to repel fleas.

Plants with anti-tungiasis effects: Eleven plants were identified to have anti-tungiasis effects, of which Musa acuminata and Odyendya gabonensis were the most cited, followed by Elaeis guineensis, Nicotiana tabacum, Morinda lucida and Piptadeniastrum africanum (Table 3). The banana core juice, palm nut pulp and tobacco leave extract or paste of other plants, mixed with or without palm oil, are applied to toes to repel or kill tungiasis. There is a wide range of anti-tungiasis plant materials depending on environmental and cultural features. In Lekoumou, Croton mayumbensis and Strychnos icaja are more commonly used. For example, the mixture of palm oil with the powder of $C$ mayumbensis barks is effective when applied to toes.

Plants with anti-dog flea effects: Four plants used to repel dog fleas (Table 3) are Strychnos icaja, Elaeis guineensis, Morinda lucida and Nicotiana tabacum. Ground bark of Strychnos icaja and leaves of Morinda lucida and Nicotiana tabacum are effective when mixed with palm oil and applied to dog skin.

Tephrosia (Delobel, and Malonga, 1987); aromatic plants like Lippia, Ocimum, Lantana, Hyptis, Cymbopogon and others including Afrostyrax (Toumnou, et al.,. 2012), Piptadeniastrum africanum ( Ojo and Ogunleye, 2013), Annona sp ( Rossini et al., 2008), 
Nicotiana tabacum and Vernonia ( Adeniyi, et al.,2010). Extracts from cassava, palm nut and kernel have also been previously reported (Shaaya, et al. 1997, Konan et al., 2003). Other species such as Croton lechleri are used both in herbal medicine and in control of pests (Jones, 2003). However, other plants mentioned are not well known as having insecticidal or repellent activity, especially the ones that were cited in Lékoumou and Sangha. Most often, they are reported only as medicinal plants. This is the case for M. fulvum (Kanteh, and Norman, 2015), Triumfetta cordifolia (Jang et al., 2014), Mucuna sloanei (Ajiwe, et al., 1997), and Psorospermum febrifugum (Félicienne et al., 2019). Genus Croton and Strychnos are both medicinal plants (Chevalier, 1947; Frederich, et al., 2003; Tchinda et al.,2012; Aldhaher et al.,2017; Aveling and Debonnet, 2010; Schmelzer, G.H., 2007; PROTA, 2019 ; Isyaka, et al., 2019. and insect poisons (Batista et al., 2009 ; Jose and Adesina, 2015). This is the first time that such a study has been undertaken in the Republic of Congo. Among the anti-

\section{ACKNOWLEDGEMENTS}

Research Council of Norway funded this work through the Malaria vector plant project; Dr Gilbert NSONGOLA from the National Herbarium of Brazzaville for insect plants cited are those, which are not used against mosquitoes. They should be tested on these pests. The study also did not identify Zanthoxylum heitzii whose insecticidal activity was revealed by Mikolo et al., 2009 and Overgaard, et al., 2014. This medicinal plant is however abundant in the Congolese environment we visited. This amounts to saying that the survey by interviews is not enough to identify local potentials. Other procedures such as the search for identical or close species to those reported in the literature can make it possible to identify species with biological activities ignored by local populations. The results of this study show that the Congolese living in the departments of Lékoumou, Niari, Kouilou and Sangha use products derived from plants to protect themselves or their pets against harmful insects and the diseases they transmit. A total of thirty-four plants have been identified, most of them being used against mosquitoes. This work should lead to the development of new, more affordable and less intoxicating anti-insect formulations.

assistance in plant identification; and all inhabitants of the localities visited for providing the information. 
Table 2: knowledge of anti-insect plants by respondents from Lékoumou, Kouilou, Niari and Sangha

\begin{tabular}{|c|c|c|c|c|c|c|}
\hline Department & Eventuality & Anti-mosquitoes & Anti-lice & Anti-tungiasis & Anti-chicken lice & Anti-dog fleas \\
\hline \multirow{4}{*}{ Lékoumou } & Yes & $18(66,7)$ & 25(92.6) & $25(92.6)$ & $15(55.6)$ & $10(37.0)$ \\
\hline & No & $9(33,3$ & $2(7.4)$ & $2(7.4)$ & $12(44.4)$ & $17(63.0$ \\
\hline & Total & $27(100)$ & $27(100)$ & $27(100)$ & $27(100)$ & $27(100.0)$ \\
\hline & Chi-square & 21,75 & 142.05 & 142.05 & $2.42(13.16)$ & 13.16 \\
\hline \multirow{4}{*}{ Kouilou Niari } & Yes & $30(60)$ & $31(62.0)$ & $28(56)$ & $30(60)$ & $27(54.0)$ \\
\hline & No & $20(40)$ & 19(38.0) & $22(44)$ & $20(40)$ & $23(46.0)$ \\
\hline & Total & $50(100)$ & 50 & $50(100)$ & $50(100)$ & $50(100)$ \\
\hline & Chi-square & 0.9 & 1.3 & 0.33 & 0.9 & 0.14 \\
\hline \multirow{5}{*}{ Sangha } & Yes & $7(63.6)$ & $11(100)$ & $9(81.8)$ & $9(81.8)$ & $3(27.3)$ \\
\hline & No & $4(36.4)$ & $0(0.0)$ & $2(18.2)$ & $2(18.2)$ & $8(72.7)$ \\
\hline & Total & $11(100)$ & $11(100)$ & $11(100)$ & $11(100)$ & $11(100)$ \\
\hline & Chi-square & 2,56 & 35.75 & 14.47 & 14.47 & 7.38 \\
\hline & Overall frequency (\%) & 62.5 & 76,1 & 70.4 & 61.4 & 45,4 \\
\hline
\end{tabular}

Values in brachets are percentages (\%). The critical value of $\chi 2$ is 3.84 (degree of freedom $=1 ; a=0.05$ ). The difference is significant when the chi-square value is greater than the critical value (3.84).

Table 3: List of plants with insecticidal or repellent effects traditionally used in the Republic of Congo

\begin{tabular}{|c|c|c|c|c|c|c|c|c|c|c|}
\hline \multirow[t]{2}{*}{$\mathbf{N}^{\circ}$} & \multicolumn{2}{|c|}{ Anti-mosquitoes } & \multicolumn{2}{|c|}{ Pediculicidal } & \multicolumn{2}{|c|}{ Anti-chicken fleas } & \multicolumn{2}{|c|}{ Anti-tungiasis } & \multicolumn{2}{|c|}{ Anti-fleas } \\
\hline & Species & Effect & Species & Effect & Species & Effect & Species & Effect & Species & Effect \\
\hline 1 & $\begin{array}{l}\text { Afrostyrax } \\
\text { lepidophyllu }\end{array}$ & Repellence & $\begin{array}{l}\text { Odyendya } \\
\text { gabonensis }\end{array}$ & Kill & $\begin{array}{l}\text { Capsicum } \\
\text { annuum }\end{array}$ & Repellence & Ananas comosu & Kill & $\begin{array}{c}\text { Elaeis } \\
\text { guineensis }\end{array}$ & Repellence \\
\hline 2 & $\begin{array}{l}\text { Ananas } \\
\text { comosu }\end{array}$ & Repellence & $\begin{array}{l}\text { Afrostyrax } \\
\text { lepidophyllu }\end{array}$ & Repellence & Costus sp & Repellence & $\begin{array}{l}\text { Odyendya } \\
\text { gabonensis }\end{array}$ & Kill & $\begin{array}{c}\text { Morinda } \\
\text { lucida }\end{array}$ & Repellence \\
\hline 3 & $\begin{array}{c}\text { Annona } \\
\text { senegalensis }\end{array}$ & Repellence & $\begin{array}{c}\text { Annona } \\
\text { senegalensis }\end{array}$ & Kill & Elaeis guineensis & Kill & $\begin{array}{l}\text { Capsicum } \\
\text { annuum }\end{array}$ & Kill & $\begin{array}{l}\text { Nicotiana } \\
\text { tabacum }\end{array}$ & Repellence \\
\hline 4 & $\begin{array}{c}\text { Aucoumea } \\
\text { klaineana }\end{array}$ & Repellence & Elais guinensis & Repellence & Lantana camara & Repellence & $\begin{array}{c}\text { Croton } \\
\text { mayumbensi }\end{array}$ & Kill & Strychnos & Repellence \\
\hline 5 & $\begin{array}{l}\text { Capsicum } \\
\text { annuum L. }\end{array}$ & Repellence & Mucuna slaeni & Kill & $\begin{array}{l}\text { Manihot } \\
\text { esculenta }\end{array}$ & Repellence & Dioscorea & Kill & & \\
\hline
\end{tabular}




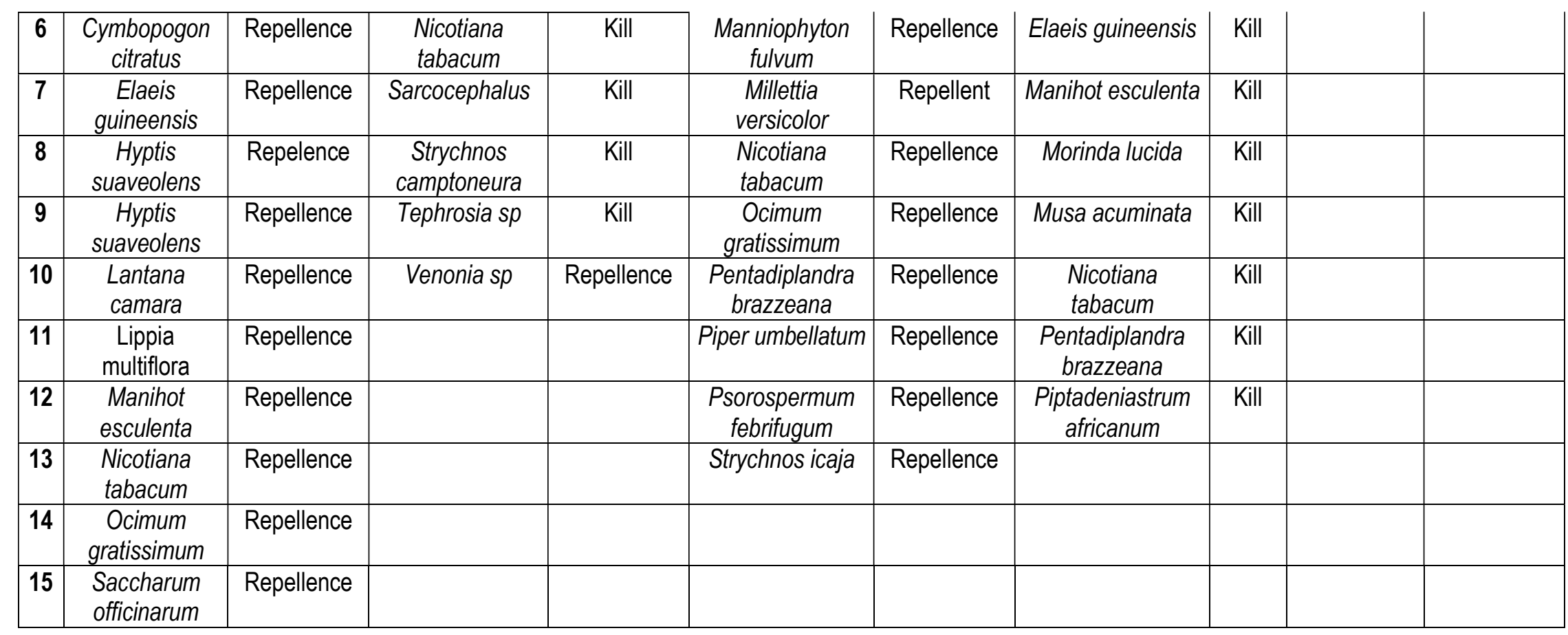




\section{REFERENCES}

Weiser, J., and Žizka, Z. (2004). Brachiola gambiae sp. $\mathrm{n}$. the Microsporidian Parasite of Anopheles gambiae and $A$. melas in Liberia. Acta Protozoologica 43: 73-80.

Peterson, C. and Coats, J. (2001) Insect repellents past, present and future. Pesticide Outlook 12: 154-8.

Patel, E. K., Gupta, A., and Oswal, R. J. (2012). A review on: mosquito repellent methods. International Journal of Pharmaceutical, Chemical and Biological Sciences 2: 310-7

Devers, D. and Van de Weghe, J. P. (2007). Les forêts du Bassin du Congo: état des forêts 2006. Partenariat sur les Forêts $d u$ Bassin $d u$ Congo. $258 \mathrm{p}$.

De Wasseige, C., De Marcken, P., Bayol, N., Hiol, F., Mayaux, P., Desclée, B., ... and Nasi, R. (2012). Les forêts du Bassin du Congo : état des forêts 2010. Office des publications de l'Union européenne, $258 \mathrm{p}$.

Ningombam, A., Ahluwalia, V., Srivastava, C., and Walia, S. (2017). Antifeedant activity and phytochemical investigation of Millettia pachycarpa extracts against tobacco leaf eating caterpillar, Spodoptera litura (Fabricius) (Lepidoptera: Noctuidae). Journal of AsiaPacific Entomology, 20(2), 381-385.

Owolabi, M. S., Padilla-Camberos, E., Ogundajo, A. L., Ogunwande, I. A., Flamini, G., Yusuff, O. K., and Flores-Fernandez, J. M. (2014). Insecticidal activity and chemical composition of the Morinda lucida essential oil against pulse beetle Callosobruchus maculatus. The Scientific World Journal, 2014.

Delobel, A., and Malonga, P. (1987). Insecticidal properties of six plant materials against Caryedon serratus (Ol.) (Coleoptera: Bruchidae). Journal of Stored Products Research, 23(3), 173-176.

Toumnou, A. L., Seck, D., Namkosserena, S., Cisse, N., Kandioura, N., and Sembene, M. (2012). Utilisation des plantes indigènes à effet insecticide pour la protection des denrées stockées contre des insectes ravageurs à Boukoko (Centrafrique). International Journal of Biological and Chemical Sciences, 6(3), 1040-1050.

Ojo, D. O., and Ogunleye, R. F. (2013). Comparative effectiveness of the powders of some underutilized botanicals for the control of
Callosobruchus maculatus (Coleoptera: Bruchidae). Journal of Plant Diseases and Protection, 120(5-6), 227-232.

Rossini, C., Castillo, L., and González, A. (2008). Plant extracts and their components as potential control agents against human head lice. Phytochemistry Reviews, 7(1), 51-63.

Adeniyi, S. A., Orjiekwe, C. L., Ehiagbonare, J. E., and Arimah, B. D. (2010). Preliminary phytochemical analysis and insecticidal activity of ethanolic extracts of four tropical plants (Vernonia amygdalina, Sida acuta, Ocimum gratissimum and Telfaria occidentalis) against bean weevil (Acanthscelides obtectus). International Journal of Physical Sciences, 5(6), 753-762.

Shaaya, E., Kostjukovski, M., Eilberg, J. E., and Sukprakarn, C. (1997). Plant oils as fumigants and contact insecticides for the control of stored-product insects. Journal of Stored Products Research, 33(1), 7-15.

Konan, Y. L., Sylla, M. S., Doannio, J. M. C., and Traoré, S. (2003). Comparison of the effect of two excipients (karite nut butter and Vaseline) on the efficacy of Cocos nucifera, Elaeis guineensis and Carapa procera oil-based repellents formulations against mosquitoes biting in Ivory Coast. Parasite, 10(2), 181-184.

Jones, K. (2003). Review of sangre de drago (Croton lechleri)-a South American tree sap in the treatment of diarrhoea, inflammation, and insect bites, viral infections, and wounds: traditional uses to clinical research. The Journal of Alternative and Complementary Medicine, 9(6), 877-896.

Kanteh, S. M., and Norman, J. E. (2015). Diversity of plants with pesticidal and medicinal properties in southern Sierra Leone. Biological agriculture and horticulture, 31(1), 18-27

Jang, J. Y., Le Dang, Q., Choi, Y. H., Choi, G. J., Jang, K. S., Cha, B., and Kim, J. C. (2014). Nematicidal activities of 4-quinolone alkaloids isolated from the aerial part of Triumfetta grandidens against Meloidogyne incognita. Journal of agricultural and food chemistry, 63(1), 68-74.

Ajiwe, V. I. E., Okeke, C. A., Nnabuike, B., Ogunleye, G. A., and Elebo, E. (1997). Applications of oils extracted from African star apple (Chrysophyllum africanum), horse eye bean 
(Mucuna sloanei) and African pear (Dacryodes edulis) seeds. Bioresource Technology, 59(23), 259-261.

Félicienne, A., Isabelle, S. T., Pascal, T. A., Espérance, M., Rose, K. E., Eugène, A., and Maximin, S. (2019). The aqueous extract of the root bark of Psorospermum febrifugum Spach effectively corrects anaemia. Experimental study on Wistar rats. Journal of Applied Biosciences, 139, 14137-14146.

Chevalier, A. (1947). Le Strychnos icaja Bn. poison d'épreuve de l'Afrique équatoriale et du Congo belge. Journal d'agriculture traditionnelle et de botanique appliquée, 27(295), 206-214.

Frederich, M., Tits, M., and Angenot, L. (2003). Indole alkaloids from Strychnos species and their Antiplasmodial and cytotoxic Activites. Chemistry of natural compounds, 39 (6), 513519.

Tchinda, A. T., Tamze, V., Ngono, A. R., Ayimele, G. A., Cao, M., Angenot, L., and Frédérich, M. (2012). Alkaloids from the stem bark of Strychnos icaja. Phytochemistry letters, 5(1), 108-113.

Aldhaher, A., Langat, M., Ndunda, B., Chirchir, D., Midiwo, J. O., Njue, A., and Mulholland, D. (2017). Diterpenoids from the roots of Croton dichogamus Pax. Phytochemistry, 144, 1-8.

Aveling, C., and Debonnet, G. (2010). Patrimoine mondial dans le bassin du Congo. UNESCO, 64 $p$

Schmelzer, G.H., 2007. Croton haumanianus J. Léonard. In: Schmelzer, G.H. and Gurib-Fakim, A. (Editors). PROTA (Plant Resources of Tropical Africa/Ressources végétales de l'Afrique tropicale), Wageningen, Netherlands. Consulté le 24 octobre 2019.

Isyaka, S. M., Langat, M. K., Hodges, T., Selway, B., Mas-Claret, E., Mbala, B. M., and Mulholland, D. A., (2019). Unlocking secrets of Congolese biodiversity: the chemistry of Croton haumanianus (Euphorbiaceae) J. Léonard. Planta Medica, 85(18), P-228.

Batista, R., De Jesus Silva Júnior, $A$ and De Oliveira, $A$. B. (2009). Plant-derived antimalarial agents: new leads and efficient phytomedicines. Part II. Non-alkaloidal natural products. Molecules, 14(8), 3037-3072.

Jose, A. R., \& Adesina, J. M. (2015). Larvicidal Efficacy of Cola gigantea, Malacantha alnifolia and Croton zambesicus extracts as phytoinsecticides against malaria vector
Anopheles stephensi (Diptera: culicidae). Journal of Mosquito Research, 5(5), 1-5.

Mikolo, B., Matos, L., Massamba, D., Mamonekene, V., and Miller, T. (2009). Extracts from the bark of Fagara heitzii (Aubr. et Pel.) (Rutaceae) tree are toxic to two weevils and the American cockroach. Entomological Research, 39(6), 401-405.

Overgaard, H., Sirisopa, P., Mikolo, B., Malterud, K., Wangensteen, H., Zou, Y. F., and Chandre, F. (2014). Insecticidal activities of bark, leaf and seed extracts of Zanthoxylum heitzii against the African malaria vector Anopheles gambiae. Molecules, 19(12), 21276-21290. 